\title{
Changes in Accounting Solutions for Transformations of Business Companies and Cooperatives since the Beginning of 2012
}

\author{
Hana VOMÁČKOVÁ
}

\section{Introduction}

In 2012, we encountered not only a significant amendment to commercial legislation which resulted in Act No. 125/2008 Coll., regulating Transformations of Business Companies and Cooperatives (hereinafter only "ATBCC"), as amended by Act No. 355/2011 Coll., being fully amended by Act No. 66/2012 Coll., regulating Transformations of Business Companies and Cooperatives, but also significant amendments to accounting regulations, particularly to the Accounting Act No. 563/1991 Coll., (hereinafter only "AA"), as amended, and to Regulation No. 500/2002 Coll., implementing certain provisions of the Accounting Act for accounting units that are entrepreneurs, as amended (hereinafter only "Regulation 500"). In this context, it is of primary importance whether, in most cases, the amended regulation is able to provide accounting information of the required quality and whether it can be one of the guarantees that transformations can be a tool for the successful financial management of the enterprises of successor companies. Secondly, the first experiences with the application of the amended regulation are being gained together with the first findings of how the amended regulation contributes to the acquisition of accounting information for financial management which presents a true and fair view.

\footnotetext{
\# This article has been prepared with the contribution of funds from the institutional support to long-term conceptual development of research, development and innovation at the Faculty of Finance and Accounting of the University of Economics, Prague in 2012.

* Prof. Ing. Hana Vomáčková, CSc. - professor, Department of Financial Accounting and Auditig, Faculty of Finance and Accounting, University of Economics, Prague, W. Churchill Sq. 4, 13067 Prague 3, Czech Republic, <vomackov@vse.cz>.
} 
Transformations represent a significant group of transactions with firms, i.e., relatively independent business units. It is a peculiar characteristic for transformations of business companies and cooperatives that the legal concept emphasises transactions transferring the business assets of the participating companies and their members into the successor company or companies. No reference exists to an enterprise or its part even in the amended business regulation applying to the transformation of business companies. The link can be derived indirectly through the term Business Assets with the definition of an enterprise in the Commercial Code and, after the latest amendment, also in the Act regulating Transformations of Business Companies and Cooperatives. The perception that the factual substance of transformations involves transactions with enterprises forms the very basis determining the accounting methods which should be used for resolving transformations. It can be concluded, rather intuitively, from certain stipulations of the ATBCC that many transformations are understood as being a "purchase of an enterprise", or are a "matter of the formation of a new unit, or new start". From this point of view, the commercial legislation is not systematically consistent. This is probably because the above-mentioned factual concepts for transactions involving enterprises are more financialaccounting issues and they are defined in international accounting systems or in certain national accounting systems. For these factual concepts, commercial legislation indirectly takes into consideration the idea that the transactions with enterprises are usually based on purchase transactions. This is apparent, for example, in the requirement of having the business assets of the given company measured by an expert's opinion or certain particulars of the project, e.g., a merger. In commercial legislation, this requirement is usually bound by the legal status of both the participating and successor companies and whether, in the course of the transformation, a successor company issues new shares or whether a new, further stake is recognised in connection with the exchange of the stakes of shareholders in the terminated companies for the stakes in the successor company. The shares or stakes issued by the successor company represent an equivalent or settlement for the acquired enterprise and, at the same time, a settlement for shareholders of the terminated stakes in the original participating company. Commercial legislation thereby neglects a substantial fact which is important for the method of purchase, i.e., that the transaction is bound by the factual independence, from an ownership structure point of view, of both the participating and the successor companies. In many cases it is satisfied with formal legal independence, e.g., transformations which are in fact restructurings of the 
enterprises of the participating and successor companies. However, transformations of business companies are in fact purchases only where the companies participating in the transformation are independent of each other in terms of ownership. In transformations involving the merger or division of companies, the factual basis of the situation is also characterised by the fact that the successor company may be an entirely new company and the merger process then factually involves the concept of a new unit method, or a new start. The successor company in effect takes over the enterprise of the terminated company, with its assets and liabilities, and then issues to the shareholders of the terminated company stakes or shares in its registered capital and thus also its equity. ${ }^{1}$ Therefore, the concept implemented by commercial legislation is very close to the concept of the accounting method for a purchase or the creation of a new unit. Numerous transformations, in particular transformations via mergers of affiliated companies or via spin-outs or spin-offs forming a new company, do not lead to the formation of successor companies which would be independent in terms of their ownership. Such transformations merely represent the restructuring of business assets within the framework of the original ownership structures, and the application of the concept of a purchase or a new unit does not match the factual substance of a transformation.

To support the opinion that it is necessary to distinguish between purchase transformations, transformations creating new units and restructuring transformations, we refer to the concept applied to the mergers of enterprises set out IFRS. The IFRS 3 - Business Combinations standard, involving a general accounting method for purchases, with a variation for acquisitions, relates to the transactions between independent parties, since only transactions between independent parties may factually be considered as being purchases. (Sec IFRS 3, Scope (2) and Identifying a business combination (3) - IASB, 2008). Therefore, restructuring transactions cannot be resolved using a purchase or a new unit method. It is necessary to recognise the existence of the problem of identifying and recognising the factual substance of business companies and cooperatives

According to the previously applicable Commercial Code and the currently applicable ATBCC, a part of the process of transformations of business companies is also a change in the legal status of a business company. When we speak in this article of the transformations of business companies, we mean transformations in the form of mergers, divisions and transfers of assets to shareholders. We do not deal with the kind of transformations such as "a change in legal status" or "a cross-border change in a registered office". 
transformations within the context of both commercial legislation and Czech accounting law. There is a strong connection between the stipulations of commercial legislation (Act No. 513/1991 Coll., the Commercial Code and Act No. 125/2008 Coll., regulating Transformations of Business Companies and Cooperatives) and of accounting standards (see Accounting Act No. 563/1991 Coll., and the related secondary legislation), but many differences also exist which represent unnecessary obstacles from the point of view of obtaining accounting and financial information for financial management purposes. The approach currently applied in the Czech Republic is based on the supremacy of commercial legislation over accounting regulation. Commercial legislation is considered a more general level of regulation, while accounting regulation and the related secondary legislation is a more particular or specific level of regulation. This approach would be satisfactory, if the concepts of both commercial and accounting legislation were factually identical. However, a material compliance between commercial legislation concepts and accounting concepts is only partially achieved (see above).

The question is how should both commercial and accounting legislation respond to the factual substance of transformations of business companies, and how the necessary compliance of the concepts should be achieved. This question is also pertinent for the latest legislation amendment for legal and accounting solutions for the transformations of business companies.

\section{Changes in accounting solutions for transformations of business companies}

The amended commercial legislation has expanded the views on transformations of business companies and cooperatives in several directions:

a) Types of transformations. For national transformations, the existing types are preserved, i.e., merger by consolidation and amalgamation, transfer of assets to a shareholder, division with the termination of the original company and division by spin-offs, i.e., to include division with the formation of new companies, division by amalgamation and transformation by a change in legal status. In this part, only a change in terminology has been made with respect to divisions involving the termination of the participating company. This division has been 
identified as division by spinning-off. As regards to cross-border transformations, they have also been expanded to include divisions and transfers of assets to a shareholder and cross-border relocation. However, the substance of the transactions as described above has remained preserved.

b) The decisive substantive components of commercial legislation solutions have remained preserved, i.e.:

- The substantive moment of the realisation of a transaction decisive date;

- The contractual arrangement of a transaction - transformation project;

- The arrangement of information to be entered into the contract proof of the financial position of the company as at the date preceding the decisive date, and of the successor company as at the decisive date;

- Acknowledgment that a tool to prove the financial position of both participating and successor companies has to be comprehensive, provable financial information, i.e., financial statements and an opening balance sheet;

- Acknowledgment that, in some cases, it is necessary to perform a new valuation of the business assets of the participating companies for the purpose of creating the opening balance sheet of the successor company;

- Setting deadlines for the important stages in the whole process of the preparation, implementation and conclusion of the transformation process;

- Recognition of the date when the transformation is entered in the Register of Companies as the date when the transformation becomes effective.

c) Changes - expansion of the content for fulfilling the factual components of the transformation process:

The transformation decisive date is defined in Sec. 10 of the ATBCC in essentially the same way as before, i.e.:

- The decisive date of a merger, division and transfer of assets to a shareholder is the date since which the activity of the terminated companies is, from the accounting point of view, considered as 
being activity on behalf of a successor company or companies (see Sec. 10, par. 1). The term Accounting should be understood in the sense that activities are performed on behalf of a successor company, since accounting records provide information on the financial position of a corresponding economic and accounting unit - an enterprise.

- Furthermore, it remains laid down that "the decisive date shall not precede by more than 12 days the date as at which the application to enter the transformation in the Register of Companies is filed", but this is supplemented with; "the decisive date may be set at the very latest as being the date when the merger, division or transfer of assets to a shareholder is entered in the Register (see Sec. 10, par. 3).

- Par. 2 of Sec. 10, by which the act has been amended, stipulates that: "Where division by spin-out is concerned, the effects referred to in par. 1 occur only in relation to the actions relating to the assets or liabilities which are supposed to be transferred to the successor company or cooperative".

In par. 1 of Sec. 10 , the possibility of separating a decisive date from the effective date of an entry in the Register of Companies, as defined in further sections, remained preserved. The purpose of this separation, i.e., the fact that a decisive date precedes the effective date, is based on the fact that, in order to conclude a fair agreement on the transformation which is part of the project, it is essential that verified and provable financial information on the business assets being transferred from the participating companies to the successor company is available in advance. The main reason is that the most important part of an agreement on transformation is the agreement on the ratio of the exchange of the stakes of shareholders of the terminated company for the stakes in the successor company. The exchange ratio should be appropriate and justified, in other words, it should be fair. The criterion of fairness should be the value of the business assets which are merged or divided in the successor company or companies. The tool for determining this value should be the provable comprehensive accounting information of the participating companies. Therefore, the Section states that as of the decisive date, the activities of terminated companies or a divided company are considered as activities of the successor company, from the accounting point of view. This concept of the effective date corresponds to situations where the the participating companies and the successor company are owned independently. 
Regarding the changes in Sec. 10 par. 3 further; they indicate that the decisive date may be as before, factually or logically prior to, or as at, the date of the project. Information on the project will be based on the financial statements of the participating companies, i.e., on proven, verified financial information. This provides a guarantee that the financial arrangements in the transformation project will be based on objective information and the arrangements for the exchange ratio, which is derived from the structure and amount of equity that is transferred to the successor company. The use of such verified information is essential to setting a fair, appropriate and reasoned exchange ratio of stakes in the terminated company for stakes in the registered capital and equity of the successor company.

However, the amendment allows that the decisive date is determined as at the date which will follow the compilation of a project, or its release, its approval by the general meeting, or as at the date of an entry of the merger or division project or a project for transferring assets to a shareholder in the Register of Companies. This means that the financial information and the resulting stakes of shareholders in the successor company specified in the approved project or entered in the Register of Companies may not correspond to the financial information and resulting claims for the exchange ratio which are supposed to be objective as at the decisive date. What is the reason for this provision? It is factually logical only if the shareholders of the successor company do not care if the ratio of exchange is based on historical financial information. Logically, it is possible that both participating companies and the successor company or companies have the same ownership structure and any changes in the amount and structure of the equity as at the decisive date, which is later than the date of preparation of the project, will not affect the nominal amount of the stakes and is reflected only in the total equity of the successor company. If a transformation is not a restructuring, the situation should be adequately treated legally so as to ensure the general requirement that the ratio of the exchange in the transformation process should be appropriate and justified, i.e., fair. Since transformationsrestructurings are not treated separately in the ATBCC, the question may arise as to whether the new provision regulating decisive dates does not provide room for risks of legal, accounting and power manipulation in favour of a certain group of shareholders against a different group.

If we imagine the time range for determining possible dates of a merger, division or transfer of assets, this can be an interval of 12 months 
before the application for an entry in the Register of Companies or it may be set as of the actual entry. This means that there may be a period of more than 12 months or 0 days. In all cases, as at the decisive date, the assets and liabilities transferred to the successor company should be supported together with the amount and structure of equity, in particular the amount of registered capital or share premium to which the stakes of shareholders of the successor company are linked. The information stated in the project should be fixed by an entry in the Register of Companies. If the decisive date follows the preparation, release and/or approval of the project by the general meeting or if it is the same as the date of an entry in the Register of Companies, the information included in the project will not agree with the objective, real information as at the decisive date, i.e., the information from the final financial statements and the opening balance sheet. There must be a preliminary solution in the form of information from the last ordinary or extraordinary financial statements which are further specified in Czech accounting legislation as financial statements as at the decisive date prepared for the purpose of measurement (see Sec. 54, par. 2 and 3 of Regulation 500). But even this preliminary solution generally follows the solution contained in the relationship between the final financial statements and opening balance sheet. This means that the last ordinary or extraordinary financial statements or financial statements as at the balance sheet date prepared for the purpose of measurement will represent a sort of preliminary "final financial statements" and the proposed figures in the project a sort of "preliminary opening balance sheet". The subsequent solution pursuant to accounting regulations is thus very complicated and allows for many variants whose implementation may produce errors or may even be abused.

A new paragraph 2 of Sec. 10 of the Transformation Act is also worthy of consideration. It basically states that if a spin-off is concerned, the assets or liabilities may be split. A literal implementation may end in an extreme situation where any group or individual assets, or an item of assets and liabilities, but also only any group or item of liabilities may be split from the existing company. Dividing a company or cooperative either by spinning-off or spinning-out should involve the separation of a part of an enterprise which is able to function independently in a new company. In other words, it should be the material splitting of such assets and liabilities which represent the business assets of the part of the enterprise. Where an interpretation arising from the explicit formula referred to above is applied, i.e., where any asset items or even any item 
of liabilities are involved, there is room for abuse of transformations by splitting in those cases where the assets should have been sold or liabilities assigned. This creates an environment for entirely different tax solutions!

\section{Transformation projects}

Transformation projects, especially projects of mergers, divisions, or the transfer of assets, are generally defined in Secs. 14, 15, and 15a - c of the Transformation Act. The original definition is clearly defined, i.e., "The transformation of a company or cooperative is performed in accordance with a written transformation project". It is important that "A transformation project is prepared by the persons participating in the transformation", and "the date of preparation of the project is the date when the project meets all the legal requirements of the task required by law". The project must contain the particulars required by law and must be approved, published and implemented in the approved and published version (see Sec. 15, par. 3). Approval of the project is usually by way of a notarial deed except as provided in par. 4 of Sec. 15, i.e., if the project is approved by all members, or if it is a general partnership or a limited partnership.

A completely new provision is contained in Sec. 15c, which allows changes in the shareholders of the participating companies during the period from the project release to the moment when an entry is made in the Register of Companies. This fact is not considered a change in the project. However, it is necessary that the information about the change in the shareholders is obtained by all companies before the general meeting which will approve the project or, at least, prior to an entry in the Register of Companies. It is assumed (see par. 4, Sec. 15c) that a change in shareholder changes a transformation project such that a new shareholder takes their place. The information of a change in shareholders must be added to a transformation project. The required content for projects is defined in more detail for individual types of transformations and the individual legal status of the participating business companies. For example, the content for a limited liability company merger project is set out in Sec. 70. In addition to identifying the participating and successor companies, the main provisions involve the exchange ratio, merger decisive dates, the rights that the successor company shall provide to bond holders, the date since which a right to profits from shares from exchanged stakes arises, the benefits provided to statutory body members, 
changes in a memorandum of association or a new memorandum of association, and prospective additional payments to shareholders if an exchange ratio is not completely appropriate and justified.

Content of the project for a public limited liability company (a.s.) is specified primarily in Sec. 100, which contains other specific arrangements on the number of shares exchanged, their shape, form, types, transferability, nominal value or on their admission for public trading, the method for obtaining shares for exchange, the rights of shareholders for each share type, and the procedure for shareholders of a participating company entitled to the sale of shares.

Sec. 119 lists information on merger projects, which must be available one month prior to the general meeting that will approve them. In addition to the project, the financial statements of the participating companies for the three preceding periods, the final financial statements and the opening balance sheet, if the decisive date precedes the preparation of the project, or the interim financial statements, joint reports on the merger of the participating companies, and the merger expert report and expert opinion for the measurement of assets, should asset measurement be required, must be available. It is therefore evident that if the decisive date follows the date of preparing the project, the final financial statements and an opening balance sheet are not supplied. Nevertheless, it is logical that ordinary or extraordinary financial statements as at the balance sheet date to be used for measurement have to be supplied together with a kind of "preliminary opening balance sheet". This logic, however, is not stipulated in commercial law. So the question is, what are the consequences this may have? It may lead to the interpretation that the transformation project, if the decisive date follows its completion, does not have to be supported by any provable and verified information on the financial position of the participating companies, and, consequently, that even the starting and the agreed project financial position and shares of the members of the successor company do not have to be supported. The financial statements that are to be available for the transformation project must be provable. This means that they must be supported by a list of the individual assets and liabilities of the participating companies that are transferred to the successor company. In previous regulations for projects, it was directly requested that business asset items and equity that pass from the final or ordinary or extraordinary financial statements to the opening balance sheet should be stated. Usual practice often follows this principle even now, in spite of the fact that commercial law does not require it. 


\section{Financial statements - information needed for designing key exchange arrangements in the transformation project.}

In this context, ATBCC has defined since $1^{\text {st }}$ January 2001 the so called final financial statements and the opening balance sheet of the successor company, which have also been adopted in the provisions of the Accounting Act on $1^{\text {st }}$ January 2002. In the amendment to ATBCC, the final financial statements are again defined in Sec. 11 as ordinary or extraordinary financial statements prepared as at the date preceding the date of merger, division or transfer of assets (see Sec. 11, par. 1). In paragraph 3 of the same Section it states that the opening balance sheet is prepared as at the decisive date of transformation. Essentially, there is no change. The final financial statements and opening balance sheet of the successor company are tied to the decisive date; the final financial statements at the date preceding the decisive date as at 24:00 and the opening balance sheet the decisive date as at 0:00. Up to this point there is no change. The question, however, is the link between this important accounting-financial information and the financial figures and the stakes of members provided for in the merger, division or transfer of assets project, if the decisive date follows the preparation approval, or release date or even the date of an entry in the register of companies. The figures in the project and the figures of the prescribed final financial statements and opening balance sheet may be different. It may be disputed as to whether what was agreed in the project corresponds to reality and meets the requirements for the appropriate and justified ratio for the exchange of shares. As stated in the paragraph on the decisive date, the difference in the figures of business assets between the date of project preparation and the decisive date is not important for transformations-restructuring, but it is important for transformations that are merges or divisions of participating companies which do not have the same ownership structure. There is a persisting requirement, which corresponds to the normal accounting practices usually accepted by accounting regulations, that the opening balance sheet has to be accompanied by comments by which it will be evident as to how the information from the final financial statements were transformed in the opening balance sheet. It is essential that the information in the comments, at least the basic content, is unified by accounting regulations. The comments must comply with the substantive logic of the transformation process, i.e., either merger-consolidation or division-deconsolidation. The comments on the opening balance sheet are analogous to the financial statements. If the newly declared method of accounting used for the opening balance sheet means that the opening 
balance sheet statement is replaced by the accounting for the assumed assets and liabilities, after adjustments, which are linked to the consolidation or deconsolidation of the final financial statements, then the comments on the opening balance sheet could duplicate the accounting entries, which should be the opening balance sheet of a successor company.

The opening balance sheet of the successor company should be accompanied by a list of items of assets, liabilities and equity which, as at the decisive date, are transferred to the successor company. If the decisive date precedes the date of coming into force, it is necessary to separate the information in the opening balance sheet supported by verified balances of assets, liabilities and equity, any verified new measurement, verified adjustments, such as the off-setting of mutual receivables and liabilities, mutual stakes and the equity of participating companies from the information of the regular accounting of the business of the participating companies on behalf of the successor company from the decisive date to the date of termination of the participating companies.

\section{New measurement of the business assets of the participating companies for the successor company}

ATBCC requires that in many situations in transformations, the business assets of the companies concerned be measured by an expert. However, in Sec. 13, even after the amendment, the provision remains that if ATBCC requires expert measurement of the assets, that in itself does not mean that such new measurement is reflected in the financial accounting of the participating companies and in the financial accounting of the successor company. It results from other contexts in various provisions of ATBCC that are significant for the financial accounting of new measurements of business assets, if:

- The participating companies have the legal status of a joint stock company or a limited liability company, i.e., they are capital companies, for which agreement on the exchange of the stakes of the members/shareholders of the terminated or divided companies for stakes (shares) in the successor company is crucial;

- The subject of the new measurement is just the assets of the terminated company or the split assets of a company divided by spin-off;

- The successor company or companies issue new stakes or new shares for the exchange and thereby increase their share capital. 
From these provisions and certain elements of projects, such as the date as of which the members in the successor company are entitled to a share of profits, we can observe a concept that would correspond to the general concept of the purchase method of accounting, under which the purchaser - in this case, the successor company or its majority shareholder - connects participating companies by "buying" the assets of the participating companies, and paying their shareholders with the stakes/shares in the registered capital and equity of the successor company. This concept is also supported by the fact that the amended legislation regulating the new measurement of business assets does not apply for the final financial statements, but only to the opening balance sheet of the successor company.

This also corresponds with the subsequent provisions of the amended accounting regulations, in particular the Accounting Act and Regulation 500. Both the Accounting Act and Regulation 500 combine remeasurement to fair value upon transformation with Sec. 24 (3) (a)(1) or (2). This paragraph of the Accounting Act basically states that if more than one component of the assets is acquired by transfer or transition, unless individual components cannot be measured under Sec. 25 of the Accounting Act, i.e., as in the acquisition or recognition of individual items when entering them in the accounting records, an entity measures individual fixed assets: a) on the acquisition of an enterprise or part thereof, even if it is a case of a company transformation (except for a change in legal status) either under point 1 or point 2.

Under point 1, it shall take over the individual items of property at book values from the accounting records of the entity from which the title to the enterprise was acquired or transferred. Under point 2, the acquirer takes over the assets newly measured pursuant to a special regulation. This is Regulation 500, which in Sec. 54, par. 2 refers to Sec. 24, (3)(a)(2). At the same time, in the next paragraph, the regulation states that the entity accounts for the measurement of assets and liabilities at fair value in accordance with par. 2 based on an expert measurement of the assets performed for the transformation project. Here, in particular, the amended Regulation 500 in Sec. 54 par. 2 states that if ATBCC in the terminated company or the company being divided by spin-off requires measurement of the assets, the entities shall apply the measurement of assets and liabilities using the fair value measurement method under the above Sec. 24(3)(a)(1) or (2) of the act, and the successor company, which is an entity (an accounting unit) shall proceed likewise. Unlike the 
Accounting Act, the regulation in Sec. 54 par. 3 already mentions the measurement of assets and liabilities at fair value. In connection with the new measurement of company transformations by merger or division, the said regulation actually accomplishes the concept of a general accounting method of purchase. The following is emphasized:

a) The total "acquisition (purchase) price” of the undertaking or its parts, including the transformation of the company, except for the change in legal status;

b) Two variants of measurement of the taken-over individual items of assets - assets and liabilities.

Separate sections of Regulation 500 then cover the reporting of differences between the said measurements. Sec. 6(3)(d) of Regulation 500 defines the identified difference as goodwill or negative goodwill which is reported under non-current intangible assets.

Sec. 7, par. 10 of Regulation 500 defines an item reported under tangible fixed assets, so called Gains or Losses from New Measurement of Acquired Assets. In other words, as a basis for reporting the new measurement for transformations in the opening balance sheet of the successor company, the general equation of the purchase method of accounting has two variants:

a) +,- Gain or loss to acquired assets

$=$ acquisition price of an enterprise or its part

- $\quad\left[\left(\sum\right.\right.$ individual items of assets

$-\sum$ individual items of liabilities)],

b),+- Goodwill stated at original book values

$=$ acquisition price of an enterprise or its part

$-\quad\left[\left(\sum\right.\right.$ individual items of assets

- $\sum$ individual items of liabilities)], stated at the values according to an expert opinion.

Sec. 27 of the Accounting Act, which remains to regulate measurement at fair value, is still important. The original regulation, i.e., the regulation effective until 31 December 2011, allowed that under Sec. 27, par. 3, in cases in which ATBCC requires the measurement of business assets during company transformations, the assets and liabilities be measured at fair value as at the date of measurement, i.e., as at the preparation of the financial statements (under Sec. 24(2)(b) of the Accounting Act). This 
act, in accordance with Sec. 27, considers fair value measurement as at the end of the balance sheet date or another point as at which the financial statements are prepared. New measurement must be recorded in accounting records, and reflected in the following financial statements. Now, this has been replaced in the amendment by a provision for transformations for cases where ATBCC imposes an expert measurement of the assets, stating that the measurement is regulated by implementing regulations, specifically, by Sec. 54 and Sec. 54a of Regulation 500, which refers to Sec. 24(3)(a) of the Accounting Act. This resolved a possible contradiction in interpretation that followed from an earlier version of par. 3 of Sec. 27 of the Accounting Act.

Regulation 500, in relation to the new measurement of the assumed assets and liabilities for the opening balance sheet of the successor company, mentions measurement at the so-called balance sheet date for asset measurement by an expert opinion for transformation projects. (See Sec. 14a par. 1, Sec. 54 par. 3). This balance sheet date for transformation project measurement was established because, according to ATBCC, a decisive day for the merger, division or transfer of assets can be established at the beginning of the process, and will generally be the same as the date of preparing the final financial statements and it will be reflected in the opening balance sheet as at the decisive date which shall be immediately subsequent, but can be set differently. The date may be set prior to the preparation of the project, but the measurement may be based, for example, on the last ordinary financial statements (e.g., in the case of cross-border mergers). The effective date may not only be prior to the preparation of the project, but also after the project preparation date, and as at the date of an entry in the Register of Companies at the latest. It is in these cases, if the decisive date is after the preparation, or release and approval by the general meeting, or after an entry is made in the Register of Companies, that the balance sheet date will be very important for measurement, which will always precede the project preparation, since the consequences of measurement should be reflected in the project, at least up to the amount of equity that is transferred to the successor company, and even in the structure of this equity, because its values should be decisive for the agreed exchange ratios. The project is finalised when it has all the required elements, i.e., a quantification of the registered capital of the successor company, its change, the amount and structure of other components of equity and the resulting ratio of exchange of the stakes of the members in the participating companies for stakes in the successor company or companies. Regulation 500, in the 
context of both the new measurement to fair value in mergers and the consolidation of adjustments, defines each item of equity in connection with Sec. 27, Sec. 24(3)(a) of the Accounting Act, Sec. 54 - 54b, Sec. 6 and 7 of Regulation 500, and then principally with Sec. 14a - Capital Funds and Annex No. 1, the Layout and Identification of Items in the Balance Sheet, and Section AII - Capital Funds. This defines the Capital Funds which arise as a result of new measurement regulation.

A.II.3 - Gains and losses from new measurement of assets and liabilities, serve to express the benefits or detriment from the mandatory new measurement of financial assets and liabilities to fair value, whenever the new measurement is performed in connection with the financial statements. This fund is not tied to transformations, but if such financial assets and liabilities which have been subject to mandatory measurement exist in the structure of the assumed business assets of the successor company, the fund will be transferred from the terminated company or from a spun-off part of the company to the successor company.

AII.4 Gains and losses from new measurement in transformations show "differences between the measurement of assets and liabilities in the accounting records of the terminated entity or a part of the entity divided by spin-off and a measurement of assets during the process of company transformation under the Transformation Act as at the balance sheet date for measurement. For the purposes of this regulation, the balance sheet date for measurement means the date as at which those financial accounts were prepared which were utilized for the measurement of assets by an expert for the transformation project."

AII.5 Gains or losses from transformations of companies show "differences arising from balance sheet transactions such as the mutual off-setting of receivables and liabilities, or any differences arising from the elimination of such assets and liabilities which are not reported in accordance with the regulation and the act. This item does not include losses from balance sheet transactions that are related to changes in equity under special legislation".

AII.6 Gains or losses from measurement during transformations of companies show differences in measurement "of assets and liabilities that have been recognized in the financial statements used for the measurement of assets for a company transformation project, and differences in measurement relating to disposals of assets and liabilities in 
the period from the date after the balance sheet date for measurement until the decisive day".

\section{Important points in time in the schedule for the preparation and implementation of transformations}

It is expected that the balance sheet date for measurement may not be identical with the date of the final financial statements, which are prepared as at the date preceding the decisive date of transformation. Final financial statements are required by ATBCC in general, when the decisive date precedes the date of preparation of a project. In the case of cross-border mergers, the final financial statements may not be available and then the next ordinary or extraordinary financial statements are used, the date of which will also serve as a balance sheet date for measurement. The decisive date of the transformation can be immediately, but also with some distance from the balance sheet date for measurement, or after the project preparation, but no later than as at the date of an entry in the register of companies. Therefore, Regulation 500 in Sec. 54 par. 4 and 5 regulates accounting for the new measurement of terminated entities between the balance sheet date for measurement and the decisive date. Both the commercial law and subsequent accounting treatments permit several different variants of merger, division or transfer of assets to a shareholder. Here are some basic variants:

\section{VARIANT 1:}

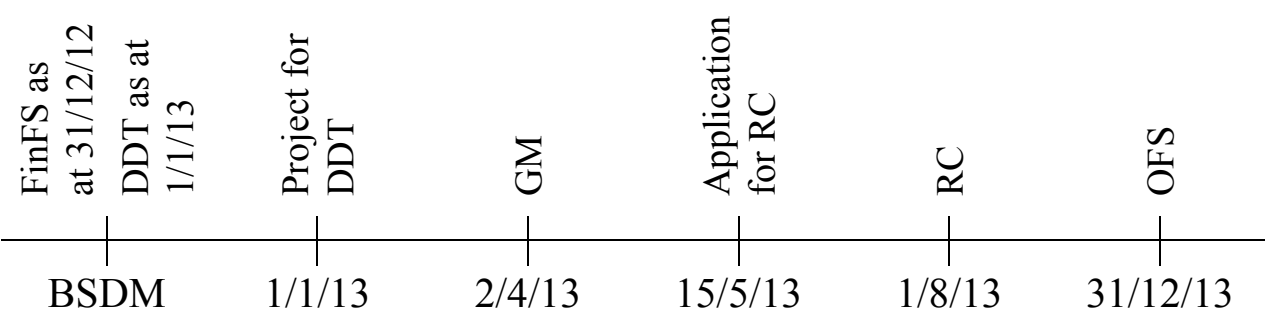

Legends: Application $=$ date of application for an entry in the register of companies, $\mathrm{BSDM}=$ balance sheet date for measurement, DDT = decisive date of transformation, $\mathrm{EFS}=$ extraordinary financial statements, FinFS = final financial statements, $\mathrm{GM}=$ General Meeting approving the project, $\mathrm{OFS}=$ ordinary financial statements, Project $=$ transformation project prepared on base in the information as at the decisive date of transformation or on the balance sheet date of transformation, $\mathrm{RC}=$ register of companies - date of an entry. 
The first variant corresponds to the procedure which was the only one stipulated in commercial and accounting regulations by the end of 2011 and is also valid from $1^{\text {st }}$ January 2012.

\section{VARIANT 2:}

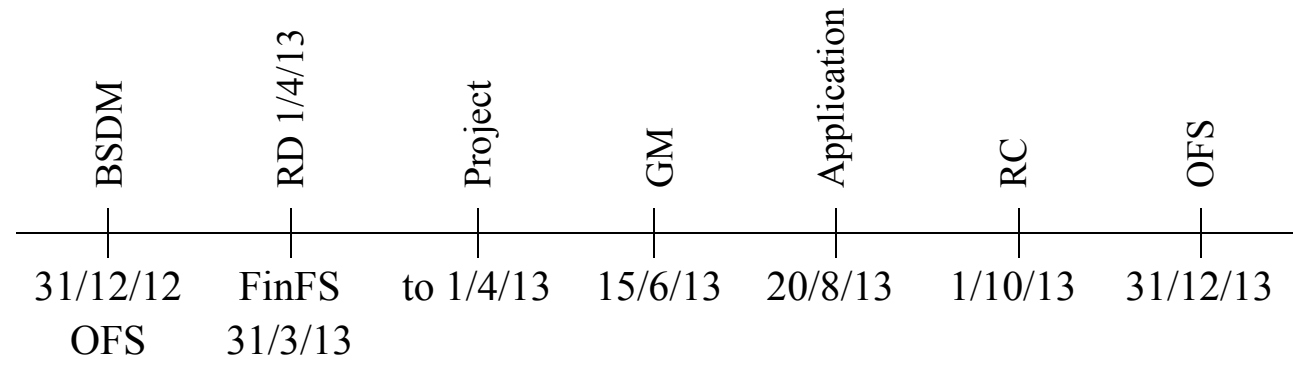

Legends: see legends for Variant 1.

The balance sheet date for transformation and the decisive date will be the same. Expert measurement will be based on the financial statements prior to the decisive date. However, it will basically be applied for the project and the opening balance sheet, but not in the final financial statements. For the measurement for the purpose of the opening balance sheet, the differences from disposals of assets and liabilities measured as at a previous date - the balance sheet date for measurement - should be reflected.

\section{VARIANT 3:}

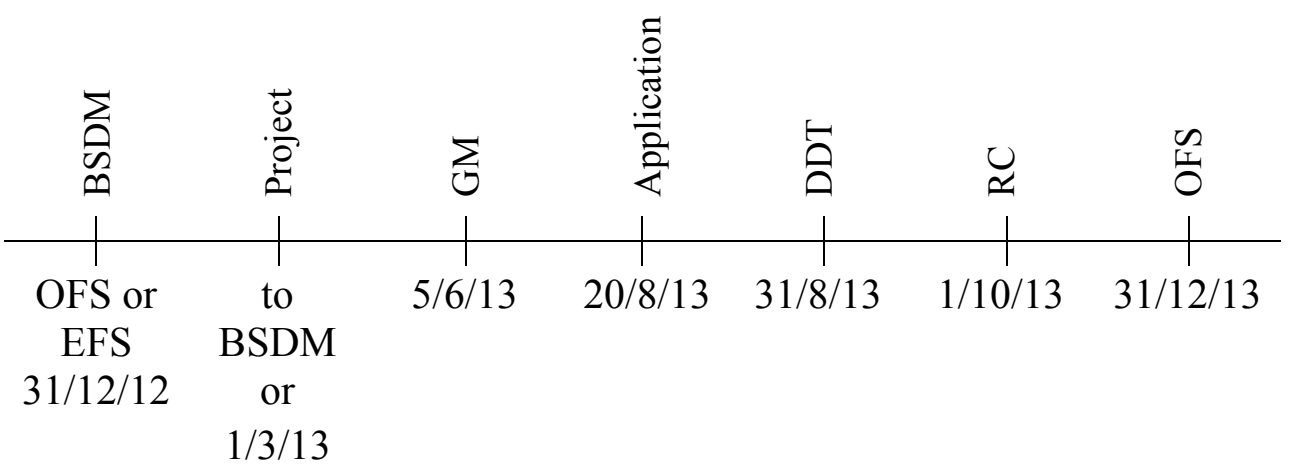

Legends: see legends for Variant 1.

In this case, the measurement bound to ordinary or extraordinary financial statements will be used, and basically from those financial 
statements and the expert measurement the amounts will be determined for the project that would otherwise be in the opening balance sheet. As at the decisive date, which will follow the completion date of the project, but before the date of an entry in the register of companies, the opening balance sheet should be drafted and the final financial statements should be prepared as at the previous day (24:00). Since the revaluation was carried out with a considerable time lag, costs according to the expert would be used for the opening balance sheet, but adjusted for disposals of re-measured assets and liabilities. In this case, it may occur that the value of opening balances will be in conflict with the values presented, or approved, and subsequently entered in the Register of Companies; in particular, this involves the values of the stakes of shareholders of the terminated company in the successor company. These differences must be dealt with in the project agreement with a provision for how to overcome them.

\section{VARIANT 4:}

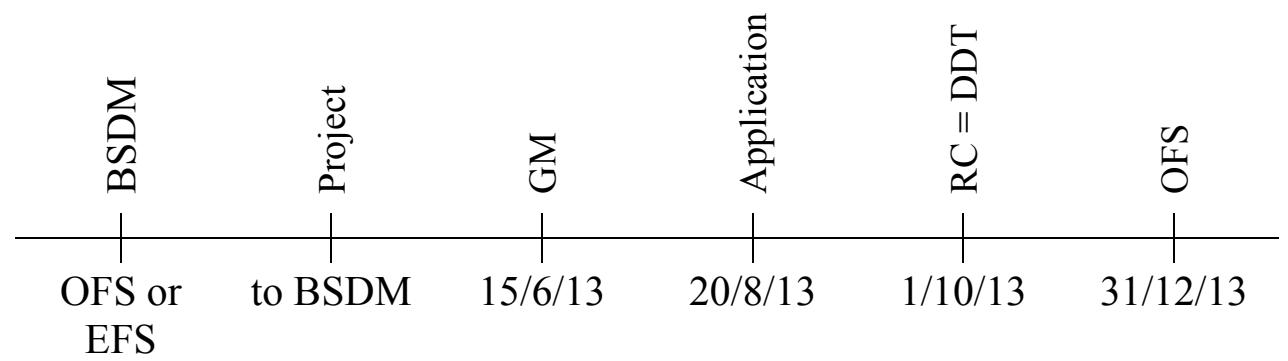

$31 / 12 / 12$

or $1 / 3 / 13$

Legends: see legends for Variant 1.

In this case, the final financial statements will be supported by a detailed review of accounts and an inventory-take performed on the occasion of the transfer as at the date preceding the decisive date, namely the date of an entry in the Register of Companies. The draft opening balance sheet will include the measurement used and adjusted for disposals of re-measured assets and liabilities. There will be the same problem as in variant 3 , i.e., the situation where the figures in the opening balance sheet will be significantly different from the figures that were included in the project, which in this case is fixed by an entry in the register of companies. Again, the way of resolving these differences must be agreed upon in the project. 
Or other variants.

In addition to the measurement method used in the transformation type of merger or division of business companies, the regulation requires accounting for the new measurement of business assets - assets and liabilities, both for the terminated company or the company divided by spin-out, and consequently also for the successor company.

The participating companies are required to account for the remeasurement of assets because the records of the future successor company will be used from the decisive date (if this precedes the date of the entry of a transformation in the register of companies). Any remeasurement of participating companies is not reflected in the final or, possibly, ordinary or extraordinary financial statements, which would have been so-called financial statements as at the decisive date for the measurement, but only in the accounting records after the decisive date, or in the case of the successor company, as at the decisive date. Since the regulation speaks of making accounting entries, the idea arises that as at the day preceding the decisive date for drawing up final financial statements the participating company will keep its original accounting records, but already from the position of acting on behalf of the successor company. The provision that the successor company will use similar accounts as of the decisive date has led to the opening balance sheet method being stipulated in the Accounting Act in Sec. 4(8)(v) and in Sec. 1 of Regulation 500. It appears that the authors of the accounting regulations assume that the opening balance sheet will be prepared based on the accounting entries, including the records of re-measurement and adjustments arising from the mutual elimination of assets and liabilities and mutual joining of the stakes, i.e., by eliminating mutual stakes and interest in the registered capital and equity, and that then it will continue with normal transactions that were performed by the participating companies on behalf of the successor company since the decisive date until the date of an entry in the Register of Companies and other ordinary transactions until the end of the first reporting period from the decisive date. I.e. that, in fact, it is not necessary to separate the information on the state of the opening balance sheet from the current business of the participating company on behalf of the successor company as at the date of termination of the participating company and the subsequent current business. 
This idea is somewhat strange, because the starting balance provides instantaneous, but also summary information on the financial position of the successor company. If the opening balance sheet is "depicted by recording in accounting records" and not separated from the transactions accounted for since the decisive date, the instantaneous, initial information on the financial position is lost. It is as if no one needed the initial financial position of the successor company to be duly presented to prove the correctness of the completion of the merger or division of a business company or the transfer of company assets to a shareholder. It is as if no one needed a basis for the financial management of the successor company from the summary financial information. This is also supported by the idea of Sec. $54 b$ of Regulation 500 that the successor entity makes its accounts only as at the date of an entry in the register of companies with effect from the decisive date. Thus, even the opening balance sheet is accounted for time-wise in the end, so it is actually expected that the participating companies, when managing the company, have not had an overall perspective, because, e.g., in the case of a merger, each of the participating companies pursued its activities on behalf of the successor company only from its partial perspective and not from the perspective of the initial financial position of the whole successor company.

The amended provisions for the decisive date have resulted in different variations of the course of capturing transformations by merger, division or transfer of assets in the accounting records. Consequently, it is required that the time progress of the movement of assets and liabilities and their measurement be tracked. For this purpose, Regulation 500 stipulates in Sec. 14a, Items - Equity Accounts, in which re-measurement to fair value should be shown and, simultaneously, it stipulates a specific accounting procedure for the participating companies and the successor company.

The equity item, Gains or losses from new measurement in company transformations, serves to show the differences from the new measurement of assets and liabilities in the accounting records of the entity terminated or divided by spin-out as at the balance sheet date for measurement. This date is understood as a date stipulated by ATBCC (see the provision on the decisive date, the date of preparing the final financial accounts or the last ordinary or extraordinary financial statements for cross-border transformations). It can thus be concluded that remeasurement under Sec. 24(3)(a)(1) or (2) will be reflected in the books of the terminated company. 
If point 1 is followed, only the total measurement of business assets or an enterprise by an expert will be available. The individual assets and liabilities of the terminated company will not be re-measured. In the books of the terminated company the following items will be accounted for after the books are opened: overall difference between the actual acquisition cost from the perspective of the successor company and the non re-measured assets and liabilities, as follows:

$$
\begin{aligned}
+,- \text { gains or losses from } & / \quad+,- \\
\text { acquired assets } & \text { gains or losses from } \\
& \text { re-measurement } \\
& \text { in transformations }
\end{aligned}
$$

Note: it can be concluded from Sec. 54 of Regulation 500 that under equity, the differences between the total acquisition costs of business assets and the differences between the carrying amounts of the individual items of business assets and their fair values will already be included under other items of equity for the successor company.

In our opinion, these values should be initially recognized in equity under gains or losses from re-measurement in transformations and subsequently used in accordance with the set structure of the equity in the project.

In the event of applying the procedure described in point 2 of the said Sec. 24(3)(a), the individual assets and liabilities of the terminated company are re-measured and the differences are reflected in the accounts - equity items and gains and losses from re-measurement in transformations. Assuming that the total value of business assets will not be determined as a measurement of an enterprise or its part, the accounting entries will be:

$$
\begin{gathered}
+,- \text { individual items of assets } \quad / \quad,+ \text { individual items of liabilities } \\
/+,- \text { gains or losses from } \\
\text { re-measurement } \\
\text { in transformations }
\end{gathered}
$$

If, within the expert measurement, the total value of business assets is determined as the measurement of an enterprise or its part and the measurement of individual items of assets and liabilities, the measurement equation and the resulting accounting procedure would be as follows:

$$
\begin{array}{cc}
+,- \text { individual items of assets } \quad / \quad,+ & \text { individual items of liabilities } \\
+,-- \text { Goodwill } & /+,- \text { gains or losses from } \\
& \text { re-measurement } \\
& \text { in transformations }
\end{array}
$$


Note: It seems that Regulation 500 does not count with this option since it fails to mention the recognition of goodwill in the accounting records of the participating company as at the decisive date, with the exception of Sec. 6(3)(d) of this regulation.

The equity item; Gains or losses from transformations of companies is to show differences arising from the elimination of mutual receivables and liabilities of the participating companies, or the eliminated assets and liabilities that are not reported in accordance with Regulation 500 and the Accounting Act. These transactions may be eligible for merging, i.e., mergers, or the transfer of assets to a shareholder. However, they already express a transaction on behalf of the successor company and this transaction can only be reported if it simultaneously has, e.g., a receivable and liability from a second or any other participating company. It cannot perform an overall elimination from the perspective of the whole successor company, unless that account contains only the elimination of its receivable or liability, which it knows will be off set or eliminated in the successor company: e.g., the elimination of a receivable against the other participating company:

Gains or losses from

transformations of companies
/ Receivable intended to be eliminated

If a participating company had both an asset and liability, it could account for it as follows:

Gains or losses from transformations of companies

Liabilities intended to be eliminated
/ Receivable intended to be eliminated

/ Gains or losses from transformation of companies

The question is, why, if the participating companies are considering a merger, for example, do they not agree in advance on a standard offsetting. This is probably because it would be virtually the final billing, which is, however, only a conditional transaction in terms of the legal effect of a merger. If the merger is not entered in the register of companies, i.e., the transformation is not effective from the legal point of view, then, all the accounting entries on behalf of the successor company would have to be cancelled by the participating company in its accounting records. 
The equity item; Gains or losses in transformation of the company is to show differences in the measurement of assets and liabilities that are re-measured as at the balance sheet date for measurement and for which disposal occurred as at the decisive date. As, during the measurement of assets and liabilities as at the balance sheet date for measurement, which would be different from the decisive date, or would not be the measurement as at the date preceding the decisive date at 24:00:00, the initially accounted for re-measurement under Gains or Losses from Remeasurement in Transformations would be transferred to the disposals of originally re-measured assets and liabilities account. This is a process related to the situation described in the item Gains or Losses from Remeasurement in Transformations using Sec. 24(2)(3)(a).

$\begin{array}{lll}\begin{array}{l}\text { Gains or losses from } \\ \text { re-measurement in } \\ \text { transformations }\end{array} & \begin{array}{l}\text { Gains or losses from measurement } \\ \text { in transformations of companies } \\ \text { (disposal of re-measured }\end{array} \\ \begin{array}{l}\text { liabilities) } \\ \text { Gains or losses from }\end{array} & / \text { Gains or losses from re- } \\ \text { measurement in } & \begin{array}{l}\text { measurement in transformations } \\ \text { (disposal of originally re- } \\ \text { transformations of companies } \\ \text { measured assets) }\end{array}\end{array}$

In the event that item 1 of the said section was applied as at the balance sheet date for measurement, any gains or losses from measurement in transformation are not accounted for. The reason is that the individual items of assets and liabilities were not re-measured.

In Sec. 54, Regulation 500 assumes that a change in the total measurement of a terminated company may occur between the balance sheet date for measurement and the decisive date, and that this change should be accounted for by adjusting the debit item of gains or losses from re-measurement to acquired assets in correspondence with the item Gains or Losses from Measurement in Transformations of Companies.

$$
\begin{aligned}
&+,- \text { gains or losses to acquired } \quad /+,- \text { gains or losses from } \\
& \text { assets } \text { measurement in } \\
& \text { transformations of companies }
\end{aligned}
$$

\begin{tabular}{|c|c|}
\hline $\begin{array}{l}-,+ \text { gains or losses from } \\
\text { measurement in } \\
\text { transformations of } \\
\text { companies }\end{array}$ & $\begin{array}{l}/-,+ \text { gains or losses to acquired } \\
\text { assets }\end{array}$ \\
\hline
\end{tabular}

or 
The extension of the right to choose the decisive date in transformations by a merger, division or the transfer of assets has excessively increased the number of variants for scheduling the transformation process and increased demands on reflection in the accounts. The reflection in the accounting records is very complicated and in many ways has become hard to understand. The idea that everything in the accounting for transformations will be supportable, if everything will be accounted for by individual accounting entries has contributed to the confusion of this reflection in accounting records.

At the same time, the inclusion of, for example, a consolidated view, i.e., the view of the successor company in the accounting records of the participating company, i.e., the terminated or spun-out company, is difficult to understand. The graduation of the reflection of remeasurement as at the balance sheet date for measurement and the distant decisive date of transformation and the reflection of gains or losses from the measurement arising under the movement, particularly disposals of assets and liabilities, considerably increases the uncertainty of accounting reflection and thus unintentionally creates conditions not only for the occurrence of errors, but also for potential manipulation with financial information. The titles of balance sheet items, particularly under equity (gains or losses from re-measurement in transformations, gains or losses from transformations, gains or losses from measurement in transformations of companies) prescribed in this context are difficult to distinguish, especially at the beginning of the application of the regulations.

Accounting for the opening balance sheet and the non-segregation of the opening balance sheet from the normal accounting transactions of the successor company since the decisive date is very misleading. Key financial information is completely lost, i.e., the financial position of the participating companies and the successor company as at the decisive date, where it must be obvious that the transformation is fair from the shareholders' point of view and that there is no detriment to minority shareholders and, by extension, creditors, debtors, employees, etc. Perhaps this approach is the unconscious result of not distinguishing between transformations which are a real "purchases" and transformations which are mere restructurings.

The terminated companies in transformations should also report their financial position as at the date of termination and the reverse posting of 
assets and liabilities makes the financial information unclear due to reversal posting. As a result, the comprehensive financial information on the participating companies as at the date of termination becomes unclear and a consolidating link to the opening balance sheet is not apparent as it is lost in the individual accounting entries.

In terms of the overall development, the latest commercial and accounting regulations for transformations appear too complex, confusing and create conditions for abuse. The question is whether, in an attempt to increase both the competitiveness of the enterprises of participating companies and the supportability of the accounting records in transformations, the opposite has not been achieved.

\section{Entering a transformation in the register of companies - becoming effective}

This is the culmination of the process of transformation by the merger, division or transfer of company assets to a shareholder. From this moment, the participating companies are either terminated or merge and one of them continues its activities in the position of the successor company with reduced business assets. The successor company adjusts as at this date the accounting records of the participating companies - that is, it should take over the accounting transactions of the terminated company from the decisive date and add them to the figures of the opening balance sheet. Since the secondary legislation stipulates that the participating company will account for all transactions, and from the decisive date also for the successor company including the merging or dividing transactions that lead to the figures of the opening balance sheet of the successor company, but always from a partial view of one of the participating companies, the successor company will have to take over these transactions from all participating companies also by accounting for them in order to "draft" the opening balance sheet in this non-standard way. The problems of this technical and organizational procedure have been analysed above. This specific problem of the method of taking over information in the opening balance sheet to the accounting records of the successor company does not occur if the decisive date is the same as the date of an entry of the merger, division or transfer of assets to a shareholder. This variant, however, is acceptable for transformations between companies with the same ownership structure in terms of the exchange ratio, i.e., for actual for transformations - restructuring. 


\section{Extending accounting methods by methods for transformations:}

If we expect that within these methods the basic method recognized for a transformation is a general purchase method of accounting, or a method of a new unit, we are very wrong. The new accounting methods include the following: a transformation method, the opening balance sheet method, the method of adjustments during cross-border transformations, the contribution or sale of the enterprise [see Sec. 4(8)(v) of the Accounting Act].

Sec. 1 of Regulation 500 lists the following methods:

- The measurement method in the transformation of a company under ATBCC, including modifications made within the framework of the transformation as at the date of an entry in the register of companies, with effect from the decisive date;

- The method of preparing the opening balance sheet in transformations;

- The method of adjustment during cross-border transformations or enterprise transfers;

- The method of acquiring more than one component of assets by transfer or transition, including measurement under Sec. 24(3)(a)(1);

- The method of valuing assets and liabilities in transformations including the moment of posting the measurement at fair value.

The above methods are, in principle, based on the concept of reflection in the accounting records of the successor company only as at the date of an entry in the register of companies with effect from the decisive date, should this date precede the date of an entry in the register of companies. The accounting rules in this case refer to the provisions of the Transformations Act, without providing a more detailed interpretation or emphasizing the factual merits of the processes. There is a return to mixing transformations with the contribution of a company or even the sale of an enterprise, which had been surpassed some time ago in previous stages of legislation development. The classification of the "new accounting methods" does not have any systematic classification criteria. The corresponding critical context has been mentioned in previous parts of this article. (see Fireš, 1987, p. 55, Kovanicová, 2005, pp. 35-47, Vomáčková, 2004, pp. 98-110). 


\section{Conclusion}

We can, therefore, say that by the amendment of ATBCC, commercial legislation has remained at the general level of transactions with business companies without distinguishing the factual merits, as a result of which transformations based on a "purchase" or a "new unit, new start" and even the "sharing of stakes" and transformations involving mere restructurings are not specifically perceived. Any direct connection between a company, its business assets and an enterprise in the economic sense of the word is, again, not addressed by legal regulations.

Czech accounting regulations do not recognize general accounting methods for transactions with enterprises in relation to mergers or divisions of business companies and cooperatives, and the transfer of assets. An indication of an unconscious partial shift to these methods is the decision that if the requirement for fair value re-measurement arises, Sec. 24(3)(a) of the Accounting Act in the variants under points 1 or 2 should be followed. Therefore, the amendment to the Accounting Act and Regulation 500 introduced in for accounting methods provides vague accounting methods, from an accountancy point of view, i.e., the transformation method and the opening balance sheet method.

It can be concluded from the issues contained in the amendments to commercial legislation and accounting law for transformations, that achieving a true and fair view of transformations in accounting records will be difficult. The amendment of the accounting rules in particular weakens the role of summary financial information, i.e., the financial statements of the participating companies and the opening balance sheets of the successor companies. Paradoxically, it weakens the importance of the fundamental accounting information necessary for the financial management of the enterprises of successor companies.

\section{References}

[1] IASB (2008): International Financial Reporting Standards (IFRSs). London, International Accounting Standards Committee Foundation, 2008.

[2] Fireš, B. (1987): Základy účetnictví. (in English: Elements Method of Financial Accounting). Praha, SNTL, 1987. 
European Financial and Accounting Journal, 2012, vol. 7, no. 3-4, pp. 33-62.

[3] Kovanicová, D. (2005): Finanční účetnictví - IAS/IFRS. (In English: Financial accounting - IAS/IFRS.). Praha, Bova Polygon, 2005.

[4] Vomáčková, H. (2009): Účetnictví akvizicí, fúzí a jiných vlastnických transakcí. (In English: Accounting for Acqusitions, Mergers and Other Proprietary Transactions, Methods of Business Combinations.) Praha, Bova Polygon, 2009. 


\title{
Changes in Accounting Solutions for Transformations of Business Companies and Cooperatives since the Beginning of 2012
}

\author{
Hana VOMÁČKOVÁ
}

\begin{abstract}
It can be concluded from an analysis and comparison of the legal and accounting concepts related to the amendment of the Transformation of Business Companies and Cooperatives Act and Regulation 500, that the amended regulations are characterized by an extensive right to choose in terms of business regulation. While the legal and accounting regulations until the end of 2011 addressed transformations generally as purchasings, the commercial and accounting regulations from $1^{\text {st }}$ January 2012 provide solutions mainly for transformations of the restructuring type. The amendment offers a high degree of choice and thus provides space for both factual concepts, however, this fact is not specified in any of the appropriate regulations. The availability of all these possible variants, from the decisive date at the very beginning of the preparation and implementation of the transformation to the recognition of an entry of a transformation in the Register of Companies, as the record date, i.e., a combination of the decisive date and the effective date, leads to a complicated accounting view that is time-consuming, often confusing and, unfortunately, does not define the conditions for recognising a transformation with the substance of a purchase and a transformation with the substance of a restructuring. Highlighting the reflection based on individual accounting transactions for the participating companies, and especially in the unusual method included in the so-called opening balance sheet method, leads to a suppression of the information links between summary financial information from the financial statements on the entry into the transformation and the summarized financial information in the form of an opening balance sheet of the successor company.
\end{abstract}

Key words: Commercial law; Financial Accounting; Acquisition; Merger; Methods for business combinations; Accounting methods for transformations in Czech law; Balance sheet date for measurement; Date of acquisition; Goodwill.

JEL classification: M41. 